\title{
New data on wild grey mullet (mugil cephalus linnaeus, 1758) myxosporean (myxobolus episquamalis egusa et al., 1990) in the black sea
}

\author{
Anna Kazarnikova ${ }^{1, *}$, Tatyana Strigakova ${ }^{2}$, Evgeny Bortnikov $^{2}$, Ovkar Byadgi $^{3}$, Marco \\ Galeotti $^{3}$, Paola Beraldo ${ }^{3}$, Alexey Ermakov ${ }^{4}$, Tatyana Derezina ${ }^{4}$ and Sarah Poynton ${ }^{5}$ \\ ${ }^{1}$ Southern Scientific Center of RAS, 41, Chekhov st., 344006, Rostov-on-Don, Russia, \\ ${ }^{2}$ The Azov Sea Research Institute of Fishery, 21-v, Beregovaya st., 344002, Rostov-on-Don, Russia \\ ${ }^{3}$ Università degli Studi di Udine, 2, Via Sondrio, 33100, Udine, Italy \\ ${ }^{4}$ Don State Technical University, 1, Gagarin Square, 344003, Rostov-on-Don, Russia \\ ${ }^{5}$ Johns Hopkins School of Medicine, Miller Research Building, Suite 855, Baltimore, MD 21205 , \\ USA
}

\begin{abstract}
Flathead grey mullet, Mugil cephalus, with mass whitish cystlike plasmodia on their scales were collected at Kerchensky preglass of the Black Sea in 2015. The prevalence of infected fish varied from $15 \%$ in spring, reached $100 \%$ in summer, and declined to $2.5 \%$ in autumn. No fish mortality was detected. The spores were oval in frontal view, tapering to a blunt apex. Two unequal polar capsules were pyriform and extended over the anterior half of spore. Spores were $8.2 \pm 0.03 \mu \mathrm{m}$ (7.9-8.4) long, $5.9 \pm 0.23 \mu \mathrm{m}$ (5.2-7.3) wide, and $4.4 \pm 0.17 \mu \mathrm{m}$ (4.0-4.7) thick. Two pyriform and unequal polar capsules were observed (4.0 $\pm 0.07 \mu \mathrm{m}(3.3-4.5)$ long, and $1.5 \pm 0.24 \mu \mathrm{m}$ (1.1-1.8) wide). The investigation of nucleotide sequences of the $18 \mathrm{~S}$ rDNA gene of the myxosporean spores from scales with universal primer A (5'-ACCTGGTTGATCCTGCCAGT-3') and B (5'-TGATCCTTCTGCAGGTTCACCTAC-3') showed 100\% identity with M. episquamalis, and $99 \%$ with $M$. bizerti, M. ichkeulensis, $M$. spinacurvata and Myxobolus sp. previously detected in mullets. The results obtained from the present study reveal that $M$. episquamalis, found on the scales of $M$. cephalus from Kerchensky preglass of the Black Sea, is new record for Russian waters.
\end{abstract}

\section{Introduction}

Flathead grey mullet (Mugil cephalus, Linnaeus, 1758) (Mugilidae) is a cosmopolitan coastal species found in tropical, subtropical and temperate zones of the Atlantic, Pacific and Indian oceans, and adjacent seas, This fish is of commercial importance in both fisheries and aquaculture. Flathead grey mullet are raised in aquaculture in the Mediterranean, south-east Asia, China, Japan, and Hawaii [6], with global production increasing from 109,466 tons in 1997 to 152,000 tons in 2014.

*Corresponding author: kazarnikova@gmail.com 
In southwest Russia, the adult mullets form huge schools near the costs of the Crimea and the Caucuses, which then migrate offshore to the Azov Sea to spawn in large aggregations [6]. The fishery is focused on the Caucasus coast in winter, and the Kerch Strait (between the Black Sea and the Azov Sea) in summer. The yield is $0.1-0.2$ thousand tons per year.

Among its parasites, flathead grey mullet serves as a host for at least 20 representatives of the genus Myxobolus: Myxobolus achmerovi (Schulman,1966), M. bizerti (Bahari and Marques, 1996), M. bramae (Reuss, 1906), M. branchialis (Markevich, 1932), M. cephalus (Iversen et al., 1971, M. cheni (Schulman, 1962), M. circulus (Achmerov, 1960), M. episquamalis (Egusa et al., 1990), M. exiguus (Thelohan, 1895), M. goensis (Eiras \& D’Souza, 2004), M. ichkeulensis (Bahri \& Marques, 1996), M. lizae (Landsberg \& Lom, 1991), M. muelleri (Butschli, 1882), M. mugcephalus (Narasimhamurti et al., 1980; Langsberg \& Lom, 1991), M. mugilii (Haldar et al., 1996), M. nile (Eiras, Molnár, 2005), M. parvus (Schulman, 1962), M. raibauti (Fall et al., 1997), M. rohdei (Lom, Dyková, 1994), M. spinacurvatura (Maeno et al., 1990), Myxobolus sp. [1;5;7-9;12-15].

Nine among these twenty species of Myxobolus have been reported from flathead grey mullet in the Black Sea: M. bramae, M. branchialis, M. circulus, M. muelleri, M. exiguous, M. exiguous, M. ichkeulensis, M. mugilii, M. parvus [12] and four - in the Mediterranean Sea: M. muelleri, M. exiguus, M. ichkeulensis and M. episquamalis. The latter is of particular concern, because it damages fish scales, adversely affecting the appearance of a commercially important species. Myxobolus episquamalis also affects three other closely related hosts: harder (Liza haematocheilus), large-scale mullet (Liza macrolepis) and thinlipped grey mullet (Liza ramada).

Our present report represents the first case of M. episquamalis infection in flathead grey mullet scales in Russian waters of the Black Sea. Numerous white cysts were detected on the scales of wild flathead grey mullet, although no mortality was associated with the infection. The morphological characteristics of the parasite and its comparison with previously published data are given. Previously, in 2000, the species had been reported from grey mullet and harder in Russian territorial waters in the Far East [13]. Myxobolus episquamalis was also recorded in grey mullet at 1987 in Peter the Great Bay, in the east of Russia, but was erroneously identified as Myxosoma acuta (= Myxobolus acutus). These studies will be an important step in monitoring the dynamics of parasite distribution in the Black Sea basin.

\section{Material and Methods}

\subsection{Sample collection}

Wild, adult flathead grey mullet were collected by trawl fishing at Kerchenskyi preglass within the Black Sea $\left(45^{\circ} 07^{\prime} \mathrm{N}, 36^{\circ} 42^{\prime} \mathrm{E}\right)$ in May, June and October 2015. 170 fish (mean total length $29.2 \pm 1.7-39.6 \pm 1.0 \mathrm{~cm}$, mean body weight $552.0 \pm 78.8-966.0 \pm 174.0 \mathrm{~g}$ ) were captured. Water temperatures were $18.4^{\circ} \mathrm{C}, 19.5^{\circ} \mathrm{C}$ and $14.0^{\circ} \mathrm{C}$ respectively.

\subsection{Parasitological examination}

Fish measurements and weight were recorded over the time (Table 1). For each month, we determined the prevalence of $M$. episquamalis (inferred by the presence of scale lesions), and 15 fish with scale lesions and 15 apparently healthy fish were taken for parasitological analysis. Fish were frozen immediately after capture. Fish were thawed before laboratory examination, and then we estimated the percentage of the fish body surface was damaged 
by the infection. The parasitological analysis was undertaken according to routine methods [3].

\subsection{Spore morphology}

Cysts on the infected scales were carefully removed, and squashed for fresh observation under the microscope (Leica DMLB). The spores were described, and morphometrics determined, according to Donets Z.S., SchulmanS.S. and LomJ., Arthur J.R. [10], in the following, the more structurally accurate term polar tubule is used instead of polar filament [2]. Giemsa-stained preparations were made to reveal the shape and location of the polar capsules.

Photographs were taken using a Leica ICC50 camera, equipped with the Leica LAS EZ software. Spore morphometrics were determined from observation of 50 spores.

\subsection{Molecular analysis}

The DNA was extracted from the homogenate using the DNeasy Tissue Kit (Qiagen) according to the manufacturer's instructions. universal primers A (5'ACCTGGTTGATCCTGCCAGT-3') (primer 1) and B (5'TGATCCTTCTGCAGGTTCACCTAC-3') (primer 6) as described by Sogin (1990) [4]. The PCR amplification of the genomic DNA, using the universal primer set, was carried out in a final volume of $50 \mu \mathrm{l}$. Subsequently, the PCR reaction was performed using a BioRad thermocycler (Bio-Rad Laboratories Inc., CA, USA) with a reaction mixture containing $100 \mathrm{ng}$ DNA, $100 \mathrm{ng}$ of each primer, and 1.25 Units HotStart Taq (Invitrogen, USA) under the following conditions: initial denaturation at $94{ }^{\circ} \mathrm{C}$ for $15 \mathrm{~min}$ followed by 35 cycles of initial denaturation $\left(94^{\circ} \mathrm{C}\right.$ for $\left.1 \mathrm{~min}\right)$, annealing $\left(55^{\circ} \mathrm{C}\right.$ for $\left.1 \mathrm{~min}\right)$, extension $\left(72{ }^{\circ} \mathrm{C}\right.$ for $\left.1 \mathrm{~min}\right)$, and a final elongation $\left(72{ }^{\circ} \mathrm{C}\right.$ for $\left.5 \mathrm{~min}\right)$.

Subsequently, $5 \mu \mathrm{l}$ of the PCR product were analyzed by $2 \%$ agarose gel electrophoresis stained with ethidium bromide, and visualized with an UV transilluminator. The molecular weight of the PCR product was determined using a $100 \mathrm{bp}$ DNA ladder (Thermo Fisher Scientific, Pittsburgh, PA, USA).

To identify the type of isolate, the PCR products were then purified using a QIAquick Purification kit (Qiagen), and directly sequenced using the forward and reverse universal primer set (https://www.eurofinsgenomics.eu/). Using a BLAST search, the sequences obtained were compared with those published in GenBank (http://blast.ncbi.nlm.nih.gov/Blast.cgi). Searched homologous sequences using BLAST program available at the NCBI website with default settings on the GenBank database. The multiple sequence alignment was performed using the CLUSTALW (http://www.ebi.ac.uk/clustalw2).

\section{Results}

\subsection{General clinical observation}

The prevalence of infection in the three months of sampling was: $15 \%$ in May, $100 \%$ in June and 2,5\% in October. Fish infected by M. episquamalis bore lesions on 30 to $90 \%$ of their body surface, with extensive damage to the scales, extending from the head posteriorly, and reaching even to the tail (Fig. 1). 




Fig. 1. Mugil cephalus with dermatitis caused by Myxobolus episquamalis. a gross image of infected fish $(\mathrm{bar}=5 \mathrm{~cm}), \mathrm{b}-$ masses of $M$. episquamalis plasmodia on scale $(\mathrm{bar}=5 \mathrm{~cm}) ; \mathrm{c}, \mathrm{d}-$ dorsal and caudal region of infected fish (bars $=3 \mathrm{~cm}$ ).

Myxobolus. episquamalis were registered on flathead grey mullet throughout study period. In the summer, all fish were infected by a parasite (Table 1).

Table 1. The mean length and weight of flathead grey mullet wild caught in May, June and October, 2015. Date shown are means and standard deviation for apparently uninfected fish and those infected by Myxobolus episquamalis.

\begin{tabular}{|l|l|c|c|c|}
\hline & & \multicolumn{3}{|c|}{ Month } \\
\hline $\begin{array}{l}\text { Length } \\
(\mathbf{c m})\end{array}$ & & May & June & October \\
\hline & & & & \\
\hline & Uninfected ( $\mathrm{n}=69)$ & $38.0 \pm 1.8^{* *}$ & No fish & $31.6 \pm 2.6$ \\
\hline & Infected (n=101) & $35.7 \pm 0.7^{*}$ & $39.6 \pm 1.0$ & $29.2 \pm 1.7$ \\
\hline & & & & \\
\hline Weight (g) & & & & $548.3 \pm 103.8$ \\
\hline & Uninfected (n $=69)$ & $837.0 \pm 138.0^{* *}$ & No fish & $552.0 \pm 78.8$ \\
\hline
\end{tabular}

Values are expressed as mean $\pm \mathrm{SD}^{*}$ : indicates significant differences at $\mathrm{P}<0,05$ between uninfected* and infected** fish

\subsection{Morphological description of Myxobolus episquamalis}

Myxobolus episquamalis formed flat white cysts, $4.7 \pm 0.24 \mathrm{~mm}$ wide and $6.2 \pm 0.29 \mathrm{~mm}$ long, on the outer surface of the apex of the scales. Adjacent to the infected scales, there was inflammation (Fig. 1). The spores were oval in front view (Fig.2), tapering anteriorly to a blunt Apex. The dimensions were: length $8.2 \pm 0.03 \mu \mathrm{m}(7.9-8.4)$, width $5.9 \pm 0.23 \mu \mathrm{m}$ $(5.2-7.3)$, and thickness $4.4 \pm 0.17 \mu \mathrm{m}(4.0-4.7)$. 

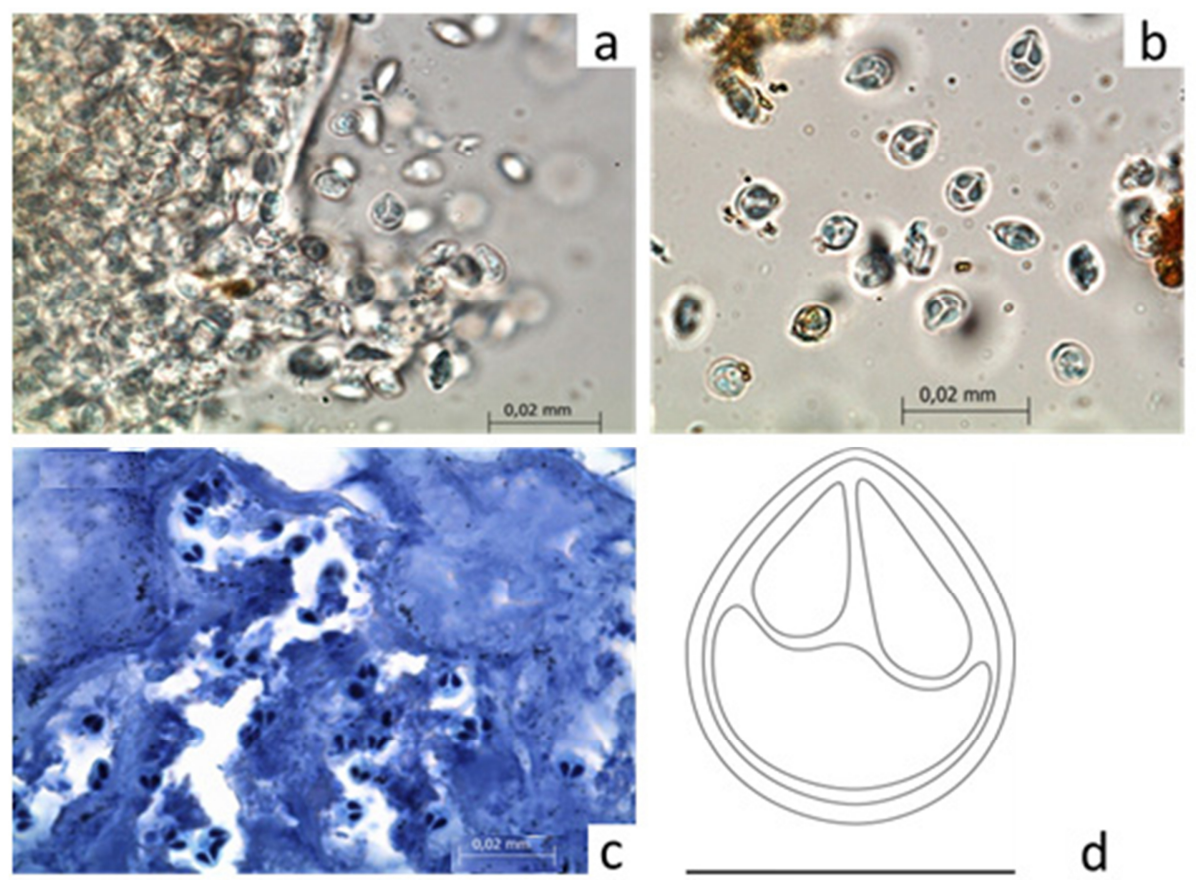

Fig. 2. Mature spores of Myxobolus episquamalis. a, b fresh preparations, c Giemsa stained spores, $\mathrm{d}$ line drawing of spore in sutural view (bar $=5 \mu \mathrm{m})$.

The two pyriforme unequal in size polar capsules, located in the anterior half of the spore, measured $4.0 \pm 0.07 \mu \mathrm{m}$ (3.3-4.5) long and $1.5 \pm 0.24 \mu \mathrm{m}$ (1.1-1.8) wide. The spores treated with Lugol's iodine had no iodinophilous vacuoles in their sporoplasm. Spore dimensions from the present study are summarized in Table 2, and compared with the previous descriptions of $M$. episquamalis.

Table 2. Biometrics of Myxobolus episquamalis spores reported from literature and present results. Measurements, in microns, are range above and mean in brackets below.

\begin{tabular}{|l|c|c|c|c|c|c|c|}
\hline & $\begin{array}{c}\text { Shed'ko, } \\
\text { Aseeva, } \\
\mathbf{2 0 0 8}[\mathbf{1 3}]\end{array}$ & $\begin{array}{c}\text { Bahri et. } \\
\text { al, 2003 } \\
{[\mathbf{1 1}}\end{array}$ & $\begin{array}{c}\text { Cho et } \\
\text { al., 2006 } \\
{[\mathbf{5}]}\end{array}$ & $\begin{array}{c}\text { Lin \& } \\
\mathbf{H o}, \mathbf{1 9 9 7} \\
{[\mathbf{9}]}\end{array}$ & $\begin{array}{c}\text { Özak et } \\
\text { al., } \\
\mathbf{2 0 1 2} \\
{[\mathbf{1 2}]}\end{array}$ & $\begin{array}{l}\text { Rothwell } \\
\text { et al., } \\
\mathbf{1 9 9 7} \text { [in } \\
\mathbf{1 ]}\end{array}$ & $\begin{array}{c}\text { Present } \\
\text { study }\end{array}$ \\
\hline Spore & & & & & & & \\
\hline Length & $8.0-9.5$ & $\begin{array}{c}8-9 \\
(8.5)\end{array}$ & $\begin{array}{c}7.26-9.35 \\
(8.25)\end{array}$ & $\begin{array}{c}8.69- \\
10.27 \\
(9.02)\end{array}$ & $\begin{array}{c}7.68- \\
8.38 \\
(8.03)\end{array}$ & $\begin{array}{c}8.8-10.0 \\
(9.2)\end{array}$ & $\begin{array}{c}7.9-8.4 \\
(8.2)\end{array}$ \\
\hline Width & $6.0-7.5$ & $\begin{array}{c}6-7 \\
(6.5)\end{array}$ & $\begin{array}{c}5.63- \\
6.78(6.3)\end{array}$ & $\begin{array}{c}5.53-7.11 \\
(6.32)\end{array}$ & $\begin{array}{c}5.63- \\
6.23 \\
(5.93)\end{array}$ & $\begin{array}{c}6.2-6.8 \\
(6.4)\end{array}$ & $\begin{array}{c}5.2-7.3 \\
(5.9)\end{array}$ \\
\hline Thickness & $5.0-6.0$ & - & $\begin{array}{c}3.96-5.04 \\
(4.34)\end{array}$ & $\begin{array}{c}4.74-5.53 \\
(5.2)\end{array}$ & $\begin{array}{c}4.75- \\
5.15 \\
(4.95)\end{array}$ & $\begin{array}{c}4.7-5 \\
(4.9)\end{array}$ & $\begin{array}{c}4.0-4.7 \\
(4.4)\end{array}$ \\
\hline Polar \\
capsule
\end{tabular}




\begin{tabular}{|c|c|c|c|c|c|c|c|}
\hline Width & $2.0-2.5$ & $\begin{array}{c}1.5- \\
2.5(2.2)\end{array}$ & $\begin{array}{l}1.62- \\
2.68\end{array}$ & $\begin{array}{c}1.58-2.37 \\
(2.35)\end{array}$ & $\begin{array}{c}1.78- \\
2.28 \\
(2.03)\end{array}$ & 1.78 & $\begin{array}{c}1.1-1.8 \\
(1.5)\end{array}$ \\
\hline \multicolumn{8}{|l|}{$\begin{array}{l}\text { Polar } \\
\text { tubule }\end{array}$} \\
\hline Length & $28-32$ & - & $\begin{array}{c}26.3- \\
56.3 \\
(39.57)\end{array}$ & $\begin{array}{c}20.54- \\
37.92 \\
(30.02)\end{array}$ & - & $48-58$ & - \\
\hline $\begin{array}{l}\text { Iodinophi } \\
\text { lous } \\
\text { vacuole }\end{array}$ & + & - & - & + & - & - & - \\
\hline \multicolumn{8}{|l|}{ Host } \\
\hline $\begin{array}{l}\text { Liza } \\
\text { haematoc } \\
\text { heilis }\end{array}$ & + & + & - & - & - & - & - \\
\hline $\begin{array}{l}\text { Liza } \\
\text { macrolepi } \\
\text { s }\end{array}$ & - & - & - & + & - & - & - \\
\hline $\begin{array}{l}\text { Liza } \\
\text { ramanda }\end{array}$ & - & + & - & - & - & - & - \\
\hline $\begin{array}{l}\text { Mugil } \\
\text { cephalus }\end{array}$ & + & + & + & - & + & + & + \\
\hline $\begin{array}{l}\text { Geograp } \\
\text { hic } \\
\text { location }\end{array}$ & Russia & Tunisia & Korea & Taiwan & Turkey & Australia & Russia \\
\hline
\end{tabular}

\subsection{Molecular characterization}

Molecular analysis using universal primer amplified consistently, and yielded the $393 \mathrm{bp}$ specific amplicon of $18 \mathrm{~S}$ rRNA of Myxobolus sp., which was confirmed using sequencing (Fig. 3).

The sequence of the 18S rRNA gene was submitted to GenBank (MG877645.1) and compared with that of other available sequences. The blast search indicates the nucleotide identity of 100\% with Myxobolus episquamalis (JF810537.1) found in grey mullet [19]; 99\% Myxobolus bizerti (AY129318.1); 99\% Myxobolus ichkeulensis (AF378337.1); 99\% with Myxobolus spinacurvata (AF378341.2) and 99\% with Myxobolus sp. (MF118764.1). 


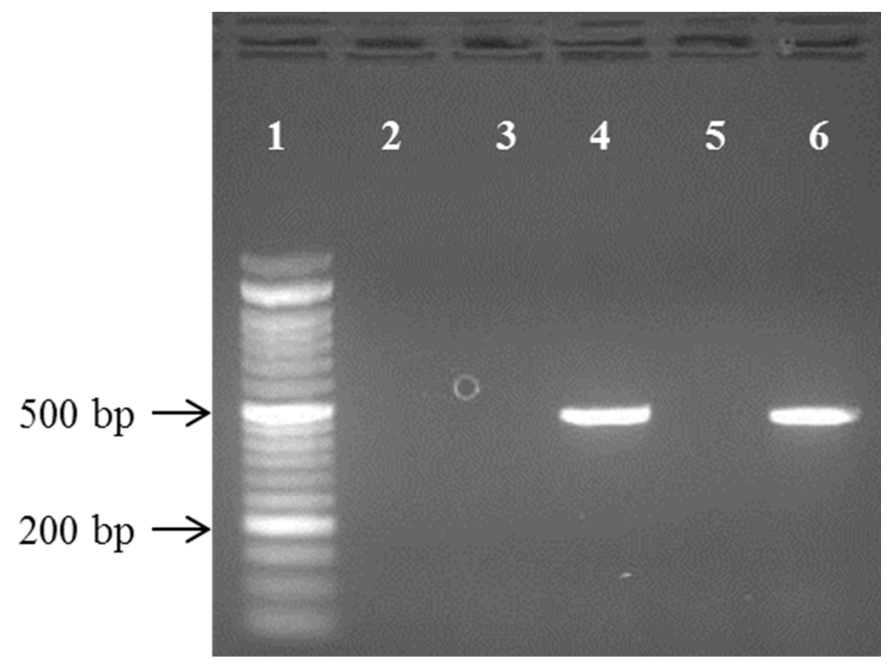

Fig. 3. Results of PCR test and Ethidium-bromide-stained agarose gel for species determination of Myxobolus parasite isolated from grey mullet lesions. Lane 1- $50 \mathrm{bp}$ DNA ladder, lane 2 negative control (double-distilled water), lane 3 and 5 - negative sample (PCR product without DNA as template), lane 4 and 6- PCR product with DNA as template.

\section{Discussion}

According to our knowledge, 22 species of Myxobolus have been recorded from grey mullet, from the following locations: Russia, Ukraine, Japan, China, Mediterranean coast of Tunis, Turkey, Italy, Israel and Egypt, South Korea, Australia, New Zealand, Thailand, USA, India and Senegal [1;5;7-9;12-15].

Among the 22 species of Myxobolus, parasites were detected in many different tissues of the fish - scale, fins, gills, brain, musculature, intestine, swim bladder, heart, liver, kidneys and spleen [11]. Only M. episquamalis damages the scales.

Fish-parasitic myxosporeans generally have strong host and tissue specificity, and well definable life cycles [10]. These characteristics, as well as spore morphology, stage was also provide valuable information for traditional taxonomic classification. The specificity of M. episquamalis is evident in its narrow host specificity for mullets (presumably reflecting their physiology and ecology), and its specialization for scale parasitism.

We identified the present specimens as $M$. episquamalis according to spore morphology, host species and target tissue, and morphometrics of the spore.

The spore dimensions of the specimens we studied, taken from hosts from the Russian waters of the Black Sea, resembled those in previous descriptions of M. episquamalis from Australia [1], Korea [5], Taiwan [9], Tunisia [1], Turkey [12] and the Russian Far East [13] (Table 2). Moreover, small differences in the size of each polar capsule due to asynchronous capsular development (Figure 2) were also observed in the present study, as was seen in some previous reports [12;13]. All of the morphological characters reported in previous descriptions coincide with our results. The absence of the iodinophilous vacuoles (observed in other studies $[1 ; 12 ; 13]$ is the difference observed between the spore samples that we examined and those reported in previous publications [9;14]. It is possible that iodinophilous vacuoles, which preserve polysaccharide in the form of $\beta$-glycogen particles [10], may disappear within a few days after the spores are freed from flathead grey mullet. We could not measure the length of polar filament because fish were frozen immediately after capture. 
Sequencing of the amplified 18s rRNA fragment of Myxobolus-specific product from the scales of our grey mullet from the Russian waters of the Black Sea, confirmed Myxobolus. Subsequent NCBI blast analysis revealed nucleotide identity of $100 \%$ with $M$. episquamalis found in Korea (JF910537.1) [8].

The scale lesions we observed were similar to those previously described in $M$. episquamalis infected mugilids [13]. The parasite formed large, flat, white cysts on the outer surface of the apex of the scale. The plasmodia penetrated the bony plate of the scale, and often caused surface erosion of the scale.

The stable functioning of the natural ecosystems is provided by a definite structure of its biotic and abiotic components. Therefore here is a high probability of M. episquamalis spreading to other new mullet hosts (Liza aurata, Liza saliens, Liza haematocheilus). This poses a threat to the mullet in the Black and the Azov Seas, which is a concern for the fishing industry and, as a flathead grey mullet, for hatcheries. Thus, it is very important to monitor other mugilid fish in the Azov-Black Sea basin for M. episquamalis infection.

The results obtained from the present study reveal that $M$. episquamalis, found on the scales of M. cephalus from the Black Sea, is new record for Russian waters. The species described in this study, together with those from previous accounts, bring the total number of Myxobolus species reported on Mugil cephalus in the Black Sea to 10: Myxobolus bramae Reuss, 1906, Myxobolus branchialis (Markevitsch, 1932), Myxobolus circulus (Achmerov, 1960), Myxobolus muelleri Bütschli, 1882; Myxobolus exiguus Thèlohan, 1895; Myxobolus episquamalis Egusa, Maeno \& Sorimachi, 1990; Myxobolus exiguous Thèlohan, 1895, Myxobolus ichkeulensis Bahri \& Marques, 1996; Myxobolus mugilii Halder et al.,1996, Myxobolus parvus Schulman, 1962.

\section{Acknowledgment}

We wish to acknowledge funding obtained from the Government of Russian Federation (contract No. 01-20-1354-245).

\section{References}

1. S. Bahri, K.B. Andree, R.P. Hedrick, Journal of Eukaryotic Microbiology 50(6), 463470 (2003)

2. J. Ben-David, S.D. Atkinson, Y. Pollak, G. Yossifon, U. Shavit, J.L. Bartholomew, T. Lotan, Parasit Vectors 9(1), 549 (2016)

3. Blue book. Suggested procedures for the detection and identification of certain finfish and shellfish pathogens (AFS FHS, 2016) https://units.fisheries.org/fhs/fish-healthsection-blue-book-2016/

4. A.C. Camus, M.J. Griffin, J. Parasitol 96(1), 116-124 (2010)

5. J.B. Cho, S.R. Kwon, M.K. Lee, M.D. Huh, K.H. Kim, Journal of Fish Pathology 19(1), 1-6 (2006)

6. Cultured aquatic species information program Mugil cephalus (Linnaeus, 1758) Food and Agricultural Organization of the United Nations (2018) http://www.fao.org/fishery/culturedspecies/Mugil_cephalus/en\#tcNA0064

7. J.C. Eiras, J. Zhang, K. Molnár, Syst Parasitol 88(1), 11-36 (2014)

8. W.S. Kim, J.H. Kim, M.J. Oh, Korean Journal of Parasitology 51(3), 369-373 (2013)

9. C.L. Lin, J.S. Ho, Journal of the Fisheries Society of Taiwan 24(3), 193-200 (1997)

10. J. Lom, J.R. Arthur, Journal of Fish Diseases 12(2), 151-156 (1989) 
11. K. Molnár, E. Eszterbauer, Myxozoan evolution, ecology and development (Springer international publishing, Cham, 2015)

12. A.A. Özak, İ. Demirkale, İ. Cengizler, Turkish Journal of Zoology 36(2), 191-199 (2012)

13. M.B. Shed'ko, N.L. Aseeva, The current state of aquatic biological resources: scientific conference dedicated to the $70^{\text {th }}$ anniversary of S.M. Konovalov (TINROtsentr, Vladivostok, 2008)

14. C. Yemmen, M.H. Ktari, S. Bahri, Acta Adriatica 52(1), 173-182 (2011)

15. V.M. Yurakhno, M.O. Ovcharenko, Parasitology Research 113(10), 3661-3674 (2014) 